\title{
THE GAZE
}

JOURNAL OF TOURISM AND HOSPITALITY

\section{COVID-19 Global Pandemic Lockdown Impact on Visit Nepal Year 2020: A Review}

\author{
Deepak Gautam \\ Institute of Forestry, Tribhuvan University, Pokhara Campus Pokhara, Nepal \\ dgautam@iofpc.edu.np \\ Aarati Khatri \\ aaratikhatri9867@gmail.com
}

Article History

Received 11 July 2020

Accepted 10 October 2020

\section{Keywords}

Tourism, revenue, generation, travel restriction, economic loss
Corresponding Editor

Ramesh Raj Kunwar kunwar.dr@gmail.com
Abstract

Tourism sector, a major backbone in revenue generation in Nepal having an immense potentiality is hardly hit by the ongoing COVID-19 pandemic that has suspended Visit Nepal Year 2020, with a theme, an experience of a life-time. This remarkable campaign is also a national development strategy in the tourism history of Nepal which aimed at attracting around 2 million foreigners from all over the world. This article is designed to explore about COVID-19 Pandemic lockdown impacts on tourism industries and Visit Nepal year 2020 Campaign. For these, secondary literature available in Google Scholar, Research Gate and, recently published newspapers were accessed. The result shows that the unprecedented and uncertain lockdown stuck millions of people in their home, lower the economic activities of different sectors of the tourism industry including hotels, homestays, travel and tours, impact on remittance, a collapse of small industries and suspension of mega projects and many more. In addition to this, this paper aims at showcasing a strong correlation between lockdown and tourism industry with perspective from Nepal Tourism Board, Academic 
practitioner, Tourism Entrepreneurs, Nepal government, ministries, Economist and Analyst to revise the protocols and safety standard of the tourism industry to massively flourish and revive amidst the pandemic and even in the post-pandemic environment.

\section{Introduction}

Nepal is a mountainous country and is mesmerizingly endowed with a natural aesthetic, has immense natural beauty and, a high level of cultural and biological diversity, heritage, and unbeatable traditional gastronomy. The exceptional trekking routes, mountaineering, wilderness area, adventure tourism, climatic condition, multi-ethnic values, rich bio-diversity flora, and fauna, snow-fed rivers are the valuable assets of the country (Shrestha, 2017).Tourism is the cornerstone to articulate the nationhood representing the authentic national cultures. It is also a country of "as many people as many gods and goddesses, as many temples as many houses, as many festivals as many days of the years".

Tourism has extended in Nepal since ancient to medieval to modern time. The development of tourism extended broader after the conquest of the Mt. Everest by Tenzing Norgay Sherpa and Edmunds Hillary in 1952. The first tourism board was established in 1958 and the first tourism plan was brought in 1972 (Nepal,2010). After that first Visit Nepal year was held in 1998 which received about 450,000 tourists skyrocketing the Nepalese economy. In 2002, “destination Nepal" was also celebrated (Gautam,2005). In 2011 also Nepal tourism year was celebrated. In 2017 alone, Nepal witnessed a record 9, 40,000 visitors, creating more than 427,000 jobs and pumping Nepali Rs. 177 billion (1 US dollar = Rs 122) into the economy (Nepal Tourism Statistics, 2019). After a glorious success of Tourism Year 'Visit Nepal 2011' and 'Visit Nepal 1998', a new tourism campaign was announced by the Ministry of Culture, Tourism, and Civil Aviation, Nepal with an aim to promote Nepal as a Tourism Destination. Nepal is a multi-ethnic, multi-cultural, multi-religious and multi-lingual country that consists of 125 Ethnic groups, more than 5 religious groups being over 80\% Hindu and 123 languages spoken all over Nepal which makes it peculiar for attracting the tourist all over the world to observe the lifestyle of people of Nepal (National Census, 2011).

Nepal was in its climax for planning to celebrate Visit Nepal 2020, an eminent project which aimed at attracting around 2 million foreign tourists to the economically dependent naturally blessed country who believes in "Atithidewobhwa" which means that guest is the epitome of the God in Nepal (Roy, 2009). This campaign had immense hope to uplift Nepal's tiny economy with a GDP of just $\$ 30$ billion by bagging home a predicted amount of $\$ 2$ billion (Visit Nepal, 2020). Most of the VNY 2020 strategic plan that aimed at creating about 20-lifetime experiences like Opening of Gautam Budhha Airport, Organizing an aerial sports competition, Conducting 
highest altitude musical concert on earth, organizing of the Nepal Tourism Excellence Awards and the Nepal Tourism Investment Summit, etc (Visit Nepal, 2020) all were halted due to the outbreak of the COVID-19 pandemic from Wuhan of China on 31st December 2019 (Dhami et al., 2020). The Visit Nepal 2020 campaign was also planned in order to revitalize Nepal's tourism industry after the massive destruction by earthquakes of 2015. After the disaster, the government of Nepal announces 2017 and 2018 as Visit Nepal Years to assure more no. of tourists to bounce the tourism industry after the earthquake. But According to National Planning Commission 2019 , there were very less infrastructures and facilities to warmly welcome the huge number of tourist. So the Ministry of Tourism postponed this campaign to assure complete development of all the infrastructures like road, upgradation of airports, repairing of all the historical sites and heritages, completion of all mega projects and many more not to leave any room for improvement to welcome the tourist. But all these planning and preparation finally came to an end on coffin after the wake of Coronavirus Pandemic all over the world

After the Second World War, the recent global concern COVID-19 dragged the human life towards extinction with the death increasing in logarithmic scale. COVID19 , an acute respiratory disease is striking the entire world by threatening human existence. It's commencing stage is linked with the wet market in 'Wuhan of Eastern China'. It was declared 'Outbreak' by Public Health Emergency of International concern on 30th January 2020 and recognized as 'Pandemic' on 11 March 2020 by World Health Organization. COVID-19 stands for Corona Virus Disease-19, '19' specifying identification date on 31st December 2019 (McIntosh, 2020). China, being the pioneer for releasing this bio-weapon and making earth inhabitable which resulted in 7,896,400 COVID-19 cases reported in 213 countries and the territories (WHO, 2020). There are altogether 432,887 deaths testing the limits of the hospital system and can claim an uncountable population if not controlled. Luckily 4,056,404 have already recovered (WHO, 2020). Human life is so sensitive that even a small microscopic virus-like Corona can threaten whole human existence. COVID-19 has engulfed the world with restrictions in human movements, locked down ' $1 / 3 \mathrm{rd}$ ' of the world, clogged national and international flights, closed schools, ceased seminars, gatherings and, even closed religious aspects of mankind. The COVID-19 has shown the tourism industry a blind spot by striking it with harsh reality since January 1 of 2020 and has turned all the tourism-dependent communities in a crisis.

Now, the tourist will no longer roam around the bustling cities admiring the hospitality and spending a huge dollars leaving behind the memories and boasting the selfless hospitality of Nepalese people all around the world. The empty hotels, streets, historical places, accommodation providers, museums, recreation centers, airports now resemble the ghost town. 
The objectives of this review article are (a) To assess the impact of COVID-19 pandemic to Visit Nepal 2020 (b) To assess the possible loss of income of tourism industries due to COVID-19.

\section{Methodology}

This review paper study has been conducted to find out the adverse impact on tourism future of the country with the cancellation of Visit Nepal 2020, one of the remarkable campaigns in the tourism history of Nepal. This study is simply design based on the secondary literature review of tourism of Nepal and COVID-19 pandemic related news and articles published in daily newspapers, online portals (Timilsina et al., 2020)data available in different websites of Ministry of Tourism, Nepal before June30, 2020. Collected data were qualitatively analyzed and presented in table and figures.

\section{Discussions}

The Tourism industry along with other financial institutions is tremendously sensitive to the different environmental uncertainties like a crisis, natural disasters, wars, social conflicts, epidemics, terrorisms (Huang et al., 2008). In this 21st century, climate change and global health emergencies are the recognized drivers to fluctuate the future of the Tourism Industry. Tourism, being the seasonal industry that is most active during April-March now has frozen due to on-going pandemic (Jamal \& Budke, 2020) People now satire 'Visit the Year 2020' as 'Sit Nepal 2020' due to the ongoing uncertain pandemic lockdown. The tourism sector is of immense potentiality i.e. profitable yet risky to a crisis (Jallat \& Shultz, 2011).

Most of the large budget projects of Nepal like Fast track road to Nijgadh, Gautam Buddha International Airport in Lumbini, Tribhuvan International Airport Capacity Building and, Pokhara Regional International Airport and few reconstructions and repairing process ongoing at Tribhuvan International Airport to welcome a huge number of tourists have been halted with fear of the spread of Coronavirus.

Most of the minor industries are now on the verge of collapse as even the domestic tourists are not allowed to travel. A developing country like Nepal is likely to suffer from tourism demand fluctuation. This pandemic is the worst crisis that has ever hit in the history of the Nepal tourism industry. With the speculation more than hard facts, this pandemic is a blind spot with infinity despair. People are asking money refund from their flight, no business, piled up of interest on a loan, the salary cuts, cancellation of holidays, remittance dropped results to less chance of rebound of the tourism industry.

This global pandemic has obstructed the five sectors which were separated by the Nepal government for the overall success of this campaign Visit Year 2020, to equally 
promote and develop all the sectors of this area. It includes People \& Heritages, Nature \& Wildlife, Culture Cities \& leisure, Religion \& Pilgrimage, and lastly Adventure and Outdoor (Visit Nepal, 2020)

\section{National and International arrivals}

It's a bad news for national and international travels as the international flights will be suspended and the internal borders will be sealed until June-30 as said by Energy Minister of Nepal. Out of 49 airports in Nepal where 7 are under construction, 17 are non-functional and 32 are in operation till 2020 according to Civil Aviation Authority of Nepal (Nepal Tourism Statistics, 2019).The top arrivals of visitors in Nepal is from the country like India, China, Srilanka, USA and UK (Visit Nepal, 2020 ). In the beginning of 2019 , the total tourist arrival by month in January was 81,273 (Nepal Tourism Statistics,2019) which drastically reduced to 79,686 with $2 \%$ drop compared to 2019 in January, 2020 (Nepal Tourism Board, 2020) which was also the initiation phase of global pandemic as shown in the Fig 1.In 2017, Nepal welcomed 940,218 foreign tourists (Nepal Tourism Statistics, 2019) which expects a growth of foreign tourists by 30 percent every year to meet the target of 1.5 million tourists by 2020 to successfully run the campaign Visit Nepal 2020.

The government issued a travel advisory against 'non- essential' travel due to which a large number of tourist from China, India, Iran, South Korea, Japan, Italy get restricted that hasled to the suspension of the promotional campaign of Visit Nepal 2020. The Nepalese tourism industry is the first casualty that has been hit hard by COVID-19. A single tourist spends US $45 \$$ daily in Nepal (MoCTCA, 2019) and the Visit Nepal 2020 had targeted to encourage tourist to invest $75 \$$ per day which has changed into null at present.

Nepal have a wide range of opportunity to flourish the tourism industry as it is strategically positioned between the two of the country having largest economy in the world that is India and China. China, also the pioneer for this pandemic is the second highest contributor of tourists i.e. $14.37 \%$ to the economy in Nepal but with the travel restrictions and lockdown is heavily suffering (Central Bureau of Statistics, 2020).The long history of the social and political relationship between Nepal and China have made the china the second largest country to contribute in the tourism sector in the recent years (Nepal Tourism Statistics, 2019) 
Fig 1: Travel arrival by year from 1993-2019

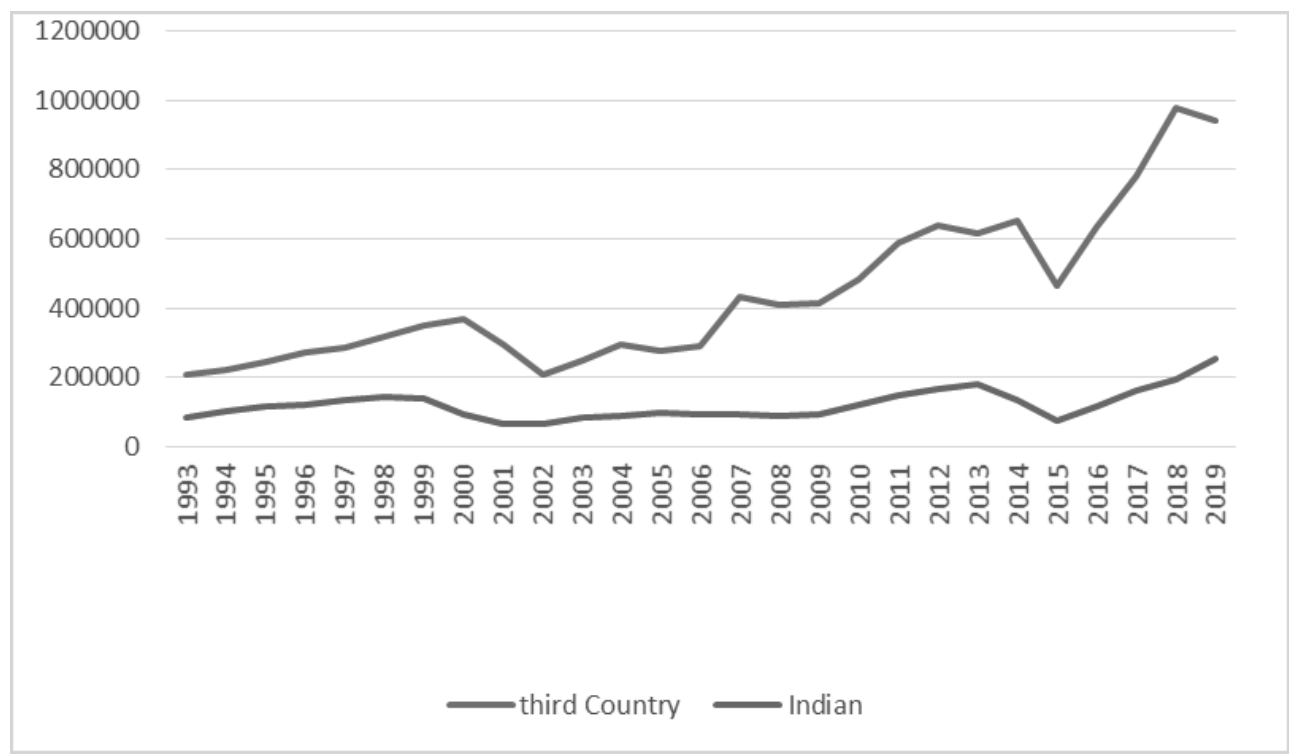

Source: Nepal Tourism Statistics, 2019

Nepal has been witnessing the rapid increasing of the tourism in 2019 with the promotion of Visit Nepal 2020 as the total no of Tourist increased from 1,173,072 in 2018 to the total number of 1,197,191 in 2019 (Department of Immigration, 2019). The total of 2, 10,205 visitors from third countries and 83,362 visitors from India only travelled to Nepal in the year 1993. With the increasing number of International and National airports and the civil services the total number jumped to 943041 visitors from third world countries and 25,4150 visitors from India alone due to the availability of easier transportation in the year 2019 making Indian visitors prominent traveler in the tourism activities of Nepal as illustrated in the Fig. 2. But the number have declined to zero due to the sealed border between Nepal and India

\section{Hotels and restaurant sector}

According to the Central Bureau of Statistics (2019) Nepal's economy is estimated to grow by $2.7 \%$ only if all the sectors except hotels and restaurants and international travel move towards normalization from Mid-May. The decline in the business amid the coronavirus pandemic have led all the hotels and restaurants of the country including the renowned well ambianced 5 stars hotel like Hyatt Regency, Radisson and Marriort are closed till the situation improves to normal. The hospitality industries have been brutally blown away, the hotel owners are pleading and the hotels have been severely suffering from this crisis as compared to previous strong performance in 2019. All the hotels of the country will be shut down till Mid- November as declared 
by the Hotel Association of Nepal (HAN). About 5.2\% of Nepal's total employment and $4.4 \%$ of the total loans by the bank is hold by hotels and restaurant. Resuming all the commercial activities, transport, hotels admits lockdown is pretty hopeless. There was around 110-star hotel with 10715 bed capacity and 886 tourist standard hotel with 28392 bed capacities back in the year 2004 which drastically increased to a total of 138-star hotel with 13,200 bed capacities and tourist standard hotel with 30799 bed capacity in the recent year 2019 as illustrated in the graph (Nepal Tourism Statistics, 2019). As the future of the lockdown has inflicted an unprecedented amount of uncertainty, it has led to the closure of both star hotels and tourist standard hotels. According to the Shreejana Rana, President of Hotel Association Nepal, the pandemic has completely down the hotel and restaurant sector as the inflow of the foreign tourist has interrupted.

\section{Holy places of Nepal}

Out of the five sectors that were included to promote in the Visit Nepal 2020, The Religion and Pilgrimage is also the one. The main holy places that have been obstructed by this pandemic are:

Table 1: Major holy places of Nepal with Visitors

\begin{tabular}{|c|c|c|}
\hline S.N & Lumbini & Pashupatinath \\
\hline Year & Visitors From Other Countries & $\begin{array}{c}\text { Visitors From Other Countries } \\
\text { Except India }\end{array}$ \\
\hline 2011 & 16,867 & 143,887 \\
\hline 2012 & 17,924 & 139,885 \\
\hline 2013 & 9685 & 156,858 \\
\hline 2014 & 14,154 & $1,66,173$ \\
\hline 2015 & 13,317 & 78,680 \\
\hline 2016 & 18,007 & 95,411 \\
\hline 2017 & 13,032 & $1,24,180$ \\
\hline 2018 & 19,279 & $1,63,311$ \\
\hline 2019 & 14,738 & $1,71,937$ \\
\hline
\end{tabular}

Source: Nepal Tourism Statistics, 2019 and Modified

\section{Lumbini}

The birthplace of Gautam Buddha, also known as "Light of Asia" is one of the major attractions for the tourist all around the world. Lumbini was listed in the World Heritage sites in 1997 as the archeological remains which were unearthed in the last century preserved in the site provides the evidence of the pilgrimage from 
the 3rd century B.C. (Kanno, 2006). Lumbini, a world heritage site is a destination for pilgrimage and religious tourism which belongs to everyone in the world as concluded by (Ghimire, 2006).in his research entitled "Lumbini: A touristic overview". Visit Lumbini 2012 was an appropriate platform for publicizing Nepal in the National and International tourism market. About 1.5 million tourist visited Lumbini from India, Nepal and from third countries in 2019 (The Rising Nepal, 2020). But with the cancellation of campaign, the figures have completely declined.

\section{Pashupatinath temple}

The sacred place was established on 477A.D with the beginning of Lichhavi kings in the history of Nepal (Nyaupane, 2019). The popularity of this sacred place is due to its ancientness, mythologies, and unshakable religious faith. Every year a huge mass of cultural tourists visits this holy place as their act of devotion. It is also the focal point for many Hindus all over the world having immense social-cultural, historical, aesthetic, and religious values. It is one among the major religious and pilgrimages destination for Hindus precisely for Saivamargis (Nyaupane, 2019)

In 2011, there were total of 63, 709 visitors from India and 16, 867 from third countries who visited Lumbini. Similarly, in 2019, the total Indian visitors increased to $2,04,825$ while there was a decline in the number of visitors from third country that counts to 14, 738 in number. Also 143887 Indian visitors visited the Pashupatinath temple in the year 2011 which increased to 171937 numbers of visitors in 2019. Around 1.5 million visited Pashupatinath temple in only 2 weeks during Mahashivaratri in 2019 (The Kathmandu Post, 2020). Similarly, another holy place Multipath, a sacred pilgrimage place for both Hindus and Buddhist all over the world was visited by 59,838 foreign visitors in the year 2018 which declined to 57,565 visitors in the year 2019 as stated by TulasiDahal, Chief of Jomsom office of Annapurna Conservation Project.

\section{National park and conservation areas}

The two national parks of Nepal namely Chitwan National park and Sagarmatha National Park has been listed in world heritage sites in 1984 and 1979 respectively by UNESCO. The world famous national park, Chitwan National park, Bardiya National park, Parsa Wildlife reserve and many more which is also the home of many endangered animals like Bengal Tiger, One-Horned Rhinocerous, Bengal Fox, Red Panda, Snow leopard etc where one can enjoy forest lifestyle and among which jungle safaris, Chitwan Jungle Safari is the most popular (Pokharel et al., 2017). This all national park having biodiversity host spotsis all shut downand is under the dark shadow of lockdown which is more likely to cause severe loss in economy. 
Table.2. Number of Foreign visitors to major protected areas of Nepal

\begin{tabular}{|l|r|r|r|r|r|}
\hline Conservation Area & $\mathbf{2 0 1 5 / 1 6}$ & $\mathbf{2 0 1 6 / 1 7}$ & $\mathbf{2 0 1 7 / 1 8}$ & $\mathbf{2 0 1 8 / 1 9}$ & $\mathbf{2 0 1 9 / 2 0}$ \\
\hline Chitwan National Park & 178257 & 87391 & 139125 & 118621 & 142486 \\
\hline Bardiya National Park & 13548 & 10638 & 17959 & 6773 & 8260 \\
\hline Langtang National Park & 12265 & 5016 & 8254 & 10619 & 12132 \\
\hline Sagarmatha National Park & 34412 & 27794 & 45112 & 56303 & 57289 \\
\hline Rara National Park & 143 & 132 & 201 & 317 & 421 \\
\hline $\begin{array}{l}\text { Annapurna Conservation } \\
\text { Area }\end{array}$ & 114418 & 83419 & 144409 & 172720 & 181746 \\
\hline Manaslu Conservation Area & 5658 & 2287 & 5745 & 7200 & 7655 \\
\hline $\begin{array}{l}\text { Gaurishanker Conservation } \\
\text { Area }\end{array}$ & 2818 & 1840 & 2770 & 2668 & 2528 \\
\hline Total & 361519 & 218517 & 363,575 & 374,951 & 412,487 \\
\hline
\end{tabular}

(Source: Department of National Park and Wildlife Conservation, Tourism Statistics 2019).

The number of visitors in the major national park and conservation areas were $3,61,519$ in the fiscal year $2015 / 2016$ which increased to $4,12,487$ in the fiscal year $2019 / 2020$ due to the alluring biodiversity provided by these conservation areas.

\section{Trekking and mountaineering}

From few years, the visitors from the Western and South Asian mostly the Chinese, Japanese and Korean have shown their keen interest on different recreational or adventurous activities like mountaineering, trekking, rafting, ecotourism, canyoning, bungee jumping (Shrestha2020) that have brought huge foreign currency in Nepal. The Best Recommended Hiking trail for Visit Nepal 2020 like Everest base camp helicopter tour ,Everest base camp trek, Annapurna Base Camp Trek, Ghorepani Poonhill trek, KhopraDanda Trek, EBC Chola Pass ,Gokyo Lake Trek, Annapurna Circuit trek, Langtang valley trek, Mardi Himal Trek, Upper mustang trek, Gosainkunda pass etc trekking routes are now empty without trekkers now .Nepal has also suspended the Everest permit over the COVID-19 issue and stopped issuing the tourist visas because of the fear that the virus may travel through the visas. The permits bring millions of dollars to Nepal every year. It is also considered as the good decision made by the government of Nepal because if more infected people enter in Nepal which can result in outbreak, then there will be 10 times more accident and same level of damage in the country according to Mingma Sherpa, Chairman of Seven Summit trek. According to Santa Bir Lama, President of Nepal Mountaineering Association, more than 3500 
travel and trekking agencies have been shut down across the country that contributes to the 600 million annually to the tourism sector due to nationwide lockdown.

In 2019, 397 members climbed Mount Everest bringing home 405800 USD royalty. Around 922 trekkers choose Mustang, 488 in Lower Dolpa, 119 in Upper Dolpa, 337 in Humla, 798 in Manaslu and 690 in Kanchenjunga were found trekking in the year 2001. With the promotion of Visit Nepal 2020 campaign all over the world, the number increased to 3739 in Mustang, 1263 in Lower Dolpa, 530 in Upper Dolpa, 8670 in Humla, 6070 in Manaslu, 911 in Kanchenjunga. The rates for tour or trekking packages for Visit Nepal 2020were lower and affordable compared to other years. So, that the Visitors can have wonderful tour and trekking packages at the costs which they have not imagined (Trekking Association of Nepal, 2020) but all these offers are valueless now.

Homestays one of the natural pattern of observing behavioral patterns of rural lifestyle with carries a theme serve what you have (Shrestha, 2017). According to Ministry of tourism, Nepal, 2018 there are altogether 324 homestays and around 800 private homestays, affecting around 40,000 employments during lockdown. As the crisis have plagued the whole world, the homestay are nearly collapsing that have hold the identity of many ethnic communities in Nepal like Gurung, Magar, Sherpa etc. due to the restriction in public movement. There will be dramatic effects on various small scale service sectors.

Economic loss due to COVID-19 pandemic in tourism industries

Table: 3. Foreign exchanging from tourism industry

\begin{tabular}{|c|c|c|c|}
\hline Year & $\begin{array}{c}\text { Total Foreign Exchange Earning } \\
\text { from tourism (Rs. in millions) }\end{array}$ & $\begin{array}{c}\text { As\%oftotal Foreign } \\
\text { Exchange Earnings }\end{array}$ & $\begin{array}{c}\text { As \% of } \\
\text { GDP }\end{array}$ \\
\hline $2009 / 10$ & $28,139.0$ & 6.0 & 2.4 \\
\hline $2010 / 11$ & $24,611.0$ & 4.9 & 1.8 \\
\hline $2011 / 12$ & $30,703.8$ & 4.5 & 1.8 \\
\hline $2012 / 13$ & $34,210.6$ & 4.5 & 2 \\
\hline $2013 / 14$ & $46,374.9$ & 4.7 & 2.4 \\
\hline $2014 / 15$ & $53,428.8$ & 4.9 & 2.5 \\
\hline $2015 / 16$ & $41,765.4$ & 3.7 & 1.9 \\
\hline $2016 / 17$ & $58,526.9$ & 4.5 & 2.3 \\
\hline $2017 / 18$ & $67,094.6$ & 9.9 & 2.2 \\
\hline
\end{tabular}




\begin{tabular}{|c|c|c|c|}
\hline Year & $\begin{array}{c}\text { Total Foreign Exchange Earning } \\
\text { from tourism (Rs. in millions) }\end{array}$ & $\begin{array}{c}\text { As\%oftotal Foreign } \\
\text { Exchange Earnings }\end{array}$ & $\begin{array}{c}\text { As \% of } \\
\text { GDP }\end{array}$ \\
\hline $2018 / 19$ & $75,808.6$ & 11.2 & \\
\hline $2019 / 20^{\star}$ & $42,736.9$ & 6.3 & \\
\hline
\end{tabular}

Source: Nepal Rastra Bank, ${ }^{\star} 1^{\text {st }}$ six month of FY 2076/77, Nepal Tourism Statistics, 2019

According to the World Travel and Tourism Council, the Travel and tourism sector contributes around 240 billion rupees into Nepal's economy and supports over 1 million job opportunities but this lockdown has created an ultimatum for the naturally bliss, eco-friendly, adventurous and natural business like tourism. The downfall of the economy is even worse than this virus. Skyrocketing stock markets have now completely declined. The COVID-19 outbreak has caused the global recession in 2020 that can further lead to the worst scenario which was once triggered in the economic crisis as of 2008-2009. As of 2019, there were 1.17 million tourists in Nepal. (MoCTCA, 2020). The tourism industry earns about 25\% of the total foreign exchange and creates more than 2,00,000 direct employment to the people making it an inseparable and distinctive place in the Nepalese economy (Asian Development Bank, Report 2019). A detailed report by the World Bank and KNOMAD in April 2020 forecast that Nepal's remittance will drop by $14 \%$ in 2020 because of the pandemic.

\section{Significance of the paper}

This paper emerges out to compare the effect of COVID-19 pandemic lockdown on diverse area of the tourism sector of Nepal and in Visit Nepal 2020, a remarkable campaign of with more than 10 years of data in the relevant field and also provides a way forward to flourish tourism industry in the crisis as well as in the post-pandemic environment. The findings suggested that the tourism industry is very profitable yet risky to a crisis.

\section{Limitation of the paper}

The limitation of this paper is that the data were taken during an ongoing pandemic and past data. So, it is very hard to speculate the conclusion of this unprecedented future of this pandemic.

\section{Conclusion}

The arrival of COVID-19, which is seen to be fretful as well as fatal to human health, has adversely affected the Visit Nepal Campaign- 2020 by creating a cessation in the number of tourists. It's high time to rethink and reboot tourism towards a better pathway for the future. The world will recover sooner or later from the pandemic just 
like the elastic rubber that rebounds after it reaches to the maximum capacity. It's totally up to us whether to take this pandemic as a golden opportunity to uplift the tourism more sustainably. Visit Nepal 2020 is the dissolution of opportunity as well as challenges to revitalize the economy. Tourism sector may be down at present but not completely out. Tourism entrepreneurs have invested a huge amount of money to make 'Visit Nepal 2020' project a lifetime experience in the history of Nepal. The government had allocated Rs 650 million (1\$=Rs122) for the campaign for this fiscal year only which ends mid-July,2020 which should be now used to provide the incentives and should use as post- recovery fund for revival of tourism sector after pandemic. Following the government instruction and WHO guidelines and also following the "COVID-19 safety and Hygiene protocol for tourism industry" introduced by the Nepal Tourism Board, 2020will work wonders to survive, revive, and prosper this global crisis and kick-start the industry with greater enthusiasm even than before.In future the immense attention is needed from various Governmental bodies, Non-Governmental bodies, political parties, different professionals, resident and non-resident, Red Cross, academicians and practitioners, Nepalese Citizens, foreign citizens to be prepared for the response to large disaster of disease and death that can collapse many sector.

\section{Acknowledgements}

We are very much thankful for chief editor and two reviewers for their constructive feedback for maintaining the quality of the paper.

\section{References}

1.5 Million Tourists Visit Lumbini in 2019. (2019, Jan 1). The Rising Nepal, (2020). Retrieved on $2^{\text {nd }}$ January.

ADB, (2019). Nepal macroeconomic update. Asian Development Bank. Retrieved from https://www.adb.org. Accessed on $10^{\text {th }}$ June 2020.

Dhami, B., Bista, S., Sadadev, B. M., Chhetri, H. B., Poudel, A., Lamichhane, A., ...\& Gautam, D. (2020). Overview of Novel Corona virus (COVID-19) and its linkage to economy of Nepal.North American Academic Research. DOI: 10.5281/ zenodo.3836903

Central Bureau of Statistics, (2020). Retrieved from: http://ghdx.healthdata.org/ organizations/central-bureau-statistics-nepal.Assessed on $2^{\text {nd }}$ June 2020.

Department of Immigration, (2019).Retrieved from: https://www.immigration.gov. $\mathrm{np} /$ post/arrival-departure-data-for-2019.Assessed on $2^{\text {nd }}$ June 2020.

Gautam, D. (2005). Growth History of Tourism in Nepal.Annual Journal of FOTSNepal. (19). 
Ghimire, H. (2006). Lumbini: A touristic overview. Lumbini: Present Status and Future Challenges. UNESCO: Kathmandu.

Huang, Y. C., Tseng, Y. P., \& Petrick, J. F. (2008). Crisis management planning to restore tourism after disasters: A case study from Taiwan. Journal of Travel \& Tourism Marketing, 23(2-4), 203-221.

Jallat, F., \& Shultz, C. J. (2011). Lebanon: From cataclysm to opportunity. Crisis management lessons for MNCs in the tourism sector of the Middle East. Journal of World Business, 46(4), 476-486.

Jamal, T., \& Budke, C. (2020). Tourism in a world with pandemics: local-global responsibility and action. Journal of Tourism Futures.

Kanno, K. (2006). Lumbini: Present status and future challenges. UNESCO: Kathmandu.

McIntosh, K. (2020). Coronavirus disease 2019 (COVID-19). UpToDate Hirsch MS Bloom, 5.

MoCTCA.(2019).Tourism Statistics. Ministry of Culture, Tourism and Civil Aviation, Kathmandu, Nepal.

MoCTCA, (2020).Tourism Statistics. Mnistry of Culture, Tourism and Civil Aviation, Kathmandu, Nepal.

Nepal Tourism Board, (2020), Retrievedfrom:https://trade.welcomenepal.com/ about-us/

Nepal Tourism Statistics, (2019).Ministry of Culture, Tourism \& Civil Aviation.

Nepal, S. (2010).13 Tourism and Political Change in Nepal. Tourism and Political Change, 147.

Nepal, S. K. (2020). Travel and tourism after COVID-19-business as usual or opportunity to reset? Tourism Geographies, 1-5.

Nepal Census, (2011) Retrived from: chromeextension:// ohfgljdgelakfkefopgklcohadegdpjf/https://unstats.un.org/unsd/demographicsocial/census/documents/Nepal/Nepal-Census-2011-Vol1.pdf

Nyaupane, P. (2019). Cultural Heritage Tourism Management in Pashupatinath Area. Nepalese Culture, 8, 95-106.

Pokharel, R., Poudel, J., Sharma, A. R., \& Grala, R. K. (2017).A study of climate variability and socioeconomic impact on tourism industry of Nepal. Sustainability in Environment, 2(1), 20-34.

Shrestha, E. (2020). With tourists staying home, homestays have no business. The Kathmandu Post. Retrieved on $29^{\text {th }}$ April. 
Shrestha, P.M. (2020). Nepali economy starts to feel the pinch as coronavirus spreads .The Kathmandu Post, April; 5, 2020

Shrestha, S. (2017). Prospect and Problem of Rural Tourism: A Case Study of Chitlang Home Stay, Makwanpur (Doctoral dissertation).

Trekking Association of Nepal, (2020), Retrieved from https://www. nepaltrekkinginhimalaya.com/pages/trekking-in-nepal-2020

Visit Nepal, (2020) retrieved from chromeextension:// ohfgljdgelakfkefopgklcohadegdpjf/https://visitnepal2020.com/wp-content/ themes/visitnepaltwenty/assets/pdf/Tabloid_VNY_Aug2019.pdf

Visit Nepal 2020 (2020, Feb 13). Tourist Arrivals: 2\% Drop in January.Retrieved on June $1^{\text {st }} 2020$.

Visit Nepal Year Campaign for 2020 and beyond: Vaida (2020, June 9). The Himalayan Times. Retrieved 2 June 2020.

WHO, (2020).Report of the WHO-China Joint Mission on Coronavirus Disease 2019 (COVID-19), February, 2020.

Xinhua, (March 29, 2020). Nepal hopes to attract $1.5 \mathrm{mln}$ tourists in 2010. Xinhua News Agency. Retrieved on 2 June 2020.

Timilsina, B., Adhikari, N., Kafle, S., Paudel, S., Poudel, S., \& Gautam, D. (2020). Addressing Impact of COVID-19 Post Pandemic on Farming and Agricultural Deeds. Asian Journal of Advanced Research and Reports, 28-35. DOI: 10.9734/ AJARR/2020/v11i430272 